Review

\title{
National Livestock Policy of Nepal: Needs and Opportunities
}

\section{Upendra B. Pradhanang ${ }^{1}$, Soni M. Pradhanang ${ }^{2, *}$, Arhan Sthapit ${ }^{3}$, Nir Y. Krakauer ${ }^{4}$, Ajay Jha ${ }^{5}$ and Tarendra Lakhankar ${ }^{6}$}

1 Shankar Dev Campus, Faculty of Management, Tribhuvan University, Kathmandu 44600, Nepal;

E-Mail: upradhananga@gmail.com

2 Department of Geosciences, University of Rhode Island, Kingston, RI 02881, USA;

E-Mail: spradhanang@uri.edu

3 Department of Management, Public Youth Campus, Tribhuvan University, Kathmandu 44600, Nepal; E-Mail: arhansthapit@gmail.com

4 Department of Civil Engineering, The City College of New York, City University of New York, New York, NY 10031, USA; E-Mail: nkrakauer@ccny.cuny.edu

5 Department of Horticulture and Landscape Architecture, College of Agricultural Sciences, Horticulture and Landscape Architecture, Colorado State University, Fort Collins, CO 80523, USA; E-Mail: ajay.jha@colostate.edu

6 NOAA-Cooperative Remote Sensing Science \& Technology (CREST) Center, The City College of New York, City University of New York, New York, NY 10031 USA; E-Mail: tlakhankar@ccny.cuny.edu

* Author to whom correspondence should be addressed; E-Mail: spradhanang@uri.edu; Tel.: +1-401-874-5980.

Academic Editor: Milan Shipka

Received: 16 October 2014 / Accepted: 3 March 2015 / Published: 17 March 2015

\begin{abstract}
This paper describes Nepal's national livestock policies and considers how they can be improved to help meet the pressing national challenges of economic development, equity, poverty alleviation, gender mainstreaming, inclusion of marginalized and underprivileged communities, and climate vulnerability. Nepal is in the process of transforming its government from a unitary system to a federal democratic structure through the new constitution expected by 2015, offering the opportunity to bring a new set of priorities and stakeholders to policymaking. Nepal's livestock subsector comes most directly within the purview of the National Agricultural Policy 2004, Agro-Business Policy, 2006 and Agricultural Sectoral Operating Policies of the Approach Paper to 13th Plan,
\end{abstract}


2012/13-2015/16 policy instruments. We systematically review these and other livestock-related national policies through analysis of their Strengths, Weaknesses, Opportunities and Threats (SWOT). We conclude with the need to formulate a separate, integrated national livestock policy so that Nepal can sustainably increase livestock productivity and achieve diversification, commercialization and competitiveness of the livestock subsector within the changing national and international contexts.

Keywords: livestock policy; federal structure; SWOT; Nepal; livelihood; climate change

\section{Introduction}

Nepal remains a predominantly agrarian economy. About 66 percent of its population is involved in agriculture, which accounts for 35 percent of the gross domestic product or GDP [1,2]. The livestock subsector of agriculture contributes 24 percent of the total agricultural GDP [3], and also plays important roles in human food and nutritional security, livelihood, regional balance, gender mainstreaming, and rural poverty alleviation [4]. Yet, there is no separate national livestock policy in Nepal, and instead, its national livestock-related policies are spread across agriculture and other sectors. The three most crucial relevant policies are National Agricultural Policy 2004 [5], Agro-Business Promotion Policy 2006 [6], and Agricultural Sectoral Operating Policies (ASOPs) [6] of the Approach Paper to Thirteenth Plan, 2012/13-2015/16. These three policy documents and a number of other livestock-related policies are reviewed in this paper with a view to building the groundwork for a new, integrated national livestock policy.

Today's changed context demands that national policies toward the livestock subsector (LSS) of the agricultural sector should be dealt with anew. While (I) unstable and increasing world food prices; (II) climate change; (III) rapidly growing regional markets; and (IV) globalized marketplaces have changed international contexts, new dimensions in the national context have resulted from (I) better connectivity (roads, internet, mobile phones); (II) outmigration and remittances; (III) movement towards decentralization and community participation; and (IV) new political developments [3].

Nepal is in the process of transforming itself from a unitary system to a federal democratic structure through the New Constitution originally expected by 22 January 2015 as per the Constituent Assembly's work schedule [3]. According to the current Interim Constitution-2007, Article 138 and 139, the organizational structure of the New Nepal-which the upcoming New Constitution will underpin - will most likely entail the democratic, inclusive and progressive restructuring of the state by replacing the centralized and unitary form of the state with a local self-governance system based on decentralization and devolution of power. This changing political context is an opportune moment to review the development of policies affecting livestock development and suggest directions for revision.

Nepal is one of the least developed countries (LDCs) in the world. In fiscal year (FY) 2012/13, its per capita income was US\$ 721, with an annual economic growth rate estimated at 3.56 percent [7]. Nepal has 23.8 percent of its people below the national poverty line (NPC, 2013). There are sharp regional disparities in economic opportunity, so that poverty is more rampant and severe in the 
Mountain and Hill regions compared to the Terai (plains) in the south and in rural areas compared to in urban areas.

Nepal is committed to alleviate extreme forms of poverty and hunger in line with the United Nations Millennium Development Goals (MDGs). The 13th Plan sets the goal to reduce poverty to 18 percent within the plan period, and to achieve 6 percent annual economic growth [6]. Nepal also has the goal of graduating to the status of a developing country from its current least-developed status by 2022. Nepal aims to achieve inclusive, wider and sustainable economic growth by integrating the contributions of the private, public and cooperative sectors in the development process.

In Nepal, the LSS has been formally recognized as an integral component of agriculture sector of the national economy at least since the inception of the First Plan in 1956. The National Agriculture Policy, 2004 [5] states that the term "Agriculture" includes LSS-related production, industry, and business. According to the National Sample Census of Agriculture-2011/12 (December 2013) [1], Nepal's livestock population stood at 22,135,058, including cattle (cows), mountain cows (yak, nak and chauri), buffaloes, goats, sheep, pigs, horses, mules, asses, rabbits and others, while domestic birds numbered 26,267,815, which encompassed poultry, ducks, pigeons and others.

Livestock farming prevails in all regions of the country, including the Mountain, Hill and Terai belts, with variations based on climate, topography, and socio-economic factors. Nepal has largely a smallholder livestock system under which farmers raise small numbers of livestock in small land holdings. Many farmers with livestock smallholdings are marginalized, close to the survival threshold and driven by subsistence needs rather than market demand. Such farmers are characterized by socio-economic vulnerability due to their inability to withstand adverse impacts from multiple stressors and risks. A common stressor is livestock mortality and morbidity due to poor nutrition and disease. The LSS has a strong gender dimension in that women contribute some 70 percent of the livestock farming work but usually have no significant role in livestock marketing and finance [3]. The LSS contributes to human food security and nutrition, livelihood of farmers, employment and income generation, inputs for farm operation (such as draft and manure), industrial production, and rural transportation.

Given the vital role of the LSS in the country's economy, the Agricultural Perspective Plan, 1995-2015 (APP) targeted growth of livestock share in AGDP from 31 percent in the pre-APP period to 45 percent, driven by livestock growth rates of 2.9 percent to 6.1 percent during the Plan period from 1995 to 2015. However, this targeted livestock growth was not achieved.

Promotion of the LSS is administered and facilitated by the Department of Livestock Services (DoLS) under the Ministry of Agricultural Development (MoAD) of the Government of Nepal (GoN) which assumes ultimate responsibility for total agricultural development including livestock development in the country, although the LSS also relates to other development and infrastructure sectors falling under different ministries and agencies. The organizational structure of DoLS includes Directorates of Animal Health, Livestock Production, Animal Services Training and Extension and Market Promotion, 5 regional directorates and 75 District Livestock Services Offices (DLSOs) with several livestock service centers and sub-centers. Other government organizations related to livestock include units of the DoLS Central Veterinary Hospital (CVH), and Veterinary Epidemiology Unit (VEU) under the Central Lab of Animal Health Directorate, as well as different laboratories. Nepal Veterinary 
Council (NVC) and Nepal Agriculture Research Council (NARC) are other, autonomous livestock-related bodies.

\section{Study Methodology}

This paper adopts a desk-research and policy-review approach aiming at a Strengths, Weaknesses, Opportunities and Threats (SWOT) analysis of the existing livestock-related national policies. SWOT is a strategic analysis technique widely used for getting an overview of the situation of any policy or organization [8]. It provides a logical framework guiding discussion and reflection about a sectoral policy via its positives (strengths and opportunities) and negatives (weaknesses and threats). We attempt to identify the factors needed for the formulation of a new national livestock policy responsive to the needs of previously underserved stakeholders, particularly the poor, and to the challenges of increasing globalization.

With these goals in mind, we first present an overview of existing livestock-related national policies of Nepal as they relate to critical issues concerning the LSS (including breeding, livestock insurance, agri-business promotion, animal health and other socioeconomic issues, Figure 1). The key national laws and planning documents from recent decades are then reviewed for their impacts on LSS using a SWOT analysis. The effects of cross-sectoral policies and interrelated macro-policies on the LSS are examined more briefly. Nepal's LSS policy regime is then discussed from the point of view of system vulnerability resulting from livelihood vulnerability and climate change vulnerability. Finally, we present the rationale for formulating a separate national livestock policy by identifying categorical premises for such a new policy and specific policy suggestions for making a new separate national livestock policy effective (Figure 1).

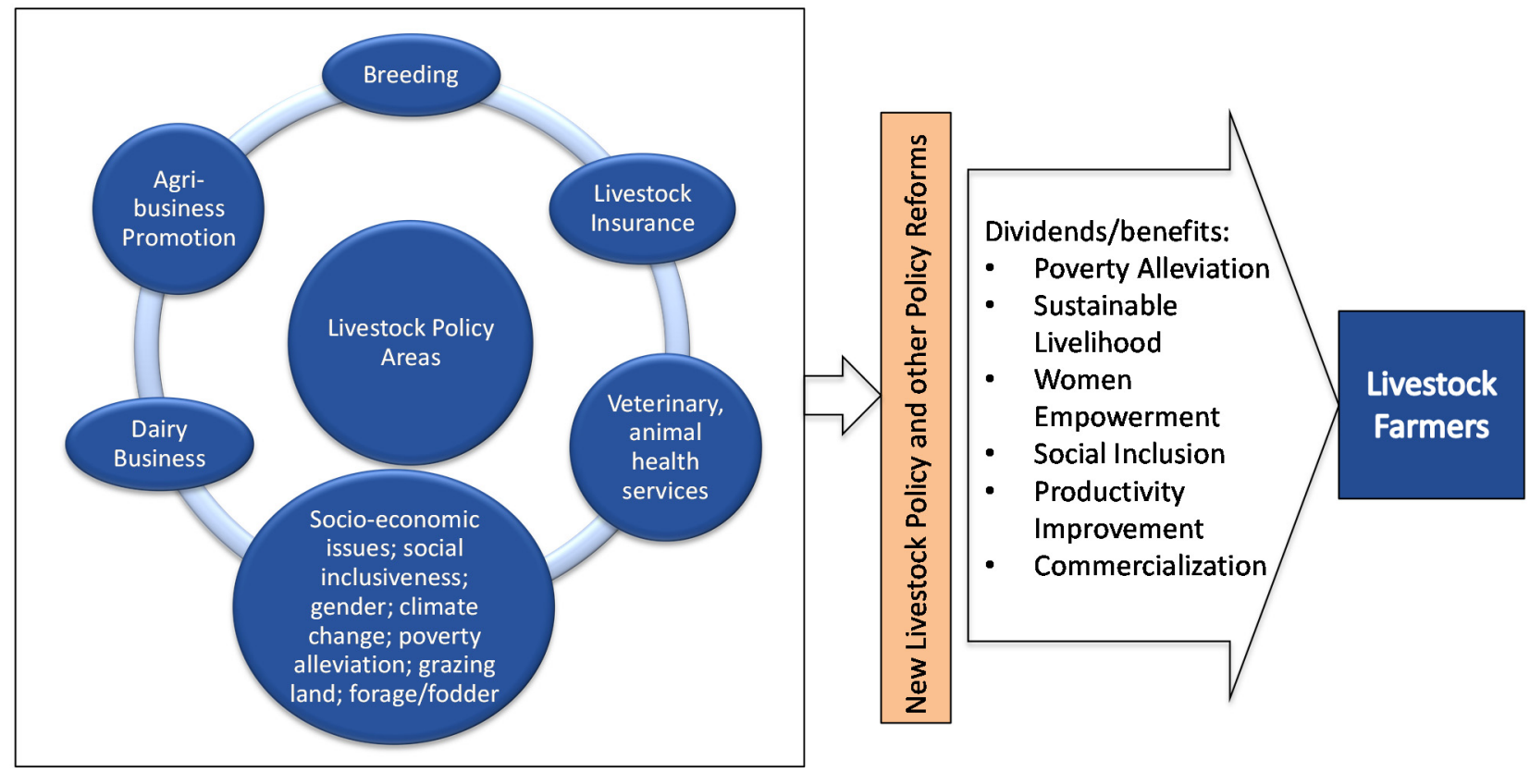

Figure 1. Model of study: interrelationships of livestock policy areas and expected outcomes (dividends) of the new livestock policy to livestock farmers and country. 


\section{Review and Analysis of Livestock-Related National Policies}

The Interim Constitution of Nepal 2007 directs Nepal as an independent, sovereign and democratic state to "develop agriculture as an industry to improve economic conditions of majority of the people dependent on agriculture" [9]. A national-level priority has been accorded to agricultural development since Nepal's planned development initiative began in 1956 with the introduction of the periodic plans. A 10-year long-term agriculture development plan was pushed forward in 1975 between the five-year periodic plans. Livestock development is subsumed under this stress on agricultural development. The Asian Development Bank (ADB) has been the major development partner supporting the LSS. The ADB assisted in the formulation of Livestock Master Plan, 1993, Agriculture Perspective Plan (APP), 1995-2015, Policies such as National Agricultural Policy, 2004 (NAP), and Agriculture Business Promotion Policy, 2007 (ABPP), and Dairy Development Policy, 2007 (DDP).

We proceed to evaluate the existing livestock-related national policies of Nepal by analyzing their strengths and weaknesses as well as their industry-specific opportunities and threats (SWOT; Figure 2) vis-à-vis the changing context of external (national and international) environments. For each policy, we contrast internal strengths and external (macro-environmental) opportunities (i.e., the SO combination) against internal weaknesses and macro-environmental threats (i.e., the WT combination). Such a policy analysis highlights positive (SO) and negative (WT) aspects that should be considered in a new LSS policy.

\begin{tabular}{|c|c|c|}
\hline $\begin{array}{l}\text { Internal Aspects } \\
\text { External Aspects } \downarrow\end{array}$ & Strengths & Weaknesses \\
\hline Opportunities & so & wo \\
\hline Threats & ST & WT \\
\hline
\end{tabular}

Figure 2. The SWOT Matrix/Grid.

Currently, the relevant major policy documents that guide livestock development are NAP, 2004; NBPP, 2007; and the Agricultural Sectoral Policy (ASP), 2013-2016 contained in the Approach Paper to the 13th Plan, 2013-2016 (TY, 2013-2016). These policy documents, analyzed in detail below using the SWOT framework, all explicitly aim at increasing livestock production and productivity and achieving diversification, commercialization and competitiveness of livestock products. Many other national policies that include livestock-related policy provisions in explicit or implicit forms (Table 1) are also discussed more briefly as they relate to the needs of the LSS.

\subsection{Agriculture Perspective Plan, 1995-2015}

The 20-year APP is a strategic document formulated in the mid-1990s and reviewed in 2001-2005 and 2006. The APP recognized livestock as one of its four priority outputs, and saw livestock as contributors to regional balance and gender mainstreaming. 
Table 1. List of main and secondary national livestock policies/plans ${ }^{1}$ reviewed.

\begin{tabular}{|c|c|c|}
\hline & Main Policies/Plans & Secondary Policies (Livestock-Related Policies in Other National Policies) \\
\hline \multirow{5}{*}{-} & & - Animal Feed Act, 1976 \\
\hline & & - Animal Health and Livestock Services Act, 1999 and Animal Health Program \\
\hline & & Implementation Procedure, 2013 \\
\hline & Agricultural Perspective Plan (APP), 1995-2015 & - Animal Slaughterhouse and Meat Inspection Act, 1999 \\
\hline & & - Labor Policy, 1999 \\
\hline \multirow{3}{*}{-} & National Agriculture Policy (NAP) 2004 & - Child Labor Act, 2000 \\
\hline & & - Forestry Sector Policy, 2000 (Forest Policy, 2000) \\
\hline & & - National Micro-Finance Policy, 2005 \\
\hline \multirow[t]{3}{*}{-} & Agro-Business Promotion Policy (ABPP), 2006 & - Dairy Development Policy, 2007 \\
\hline & & - Agriculture Bio-diversity Policy, 2007 \\
\hline & & - Trade Policy, 2009 \\
\hline & Approach Paper to the 13th Plan (2013/14-2015/16) & - Climate Change Policy, 2011 \\
\hline & and Agriculture/ Livestock Development Policies & - Breeding Policy, 2011 \\
\hline & & - Birds Rearing Policy, 2011 \\
\hline & & - Rangeland Policy, 2012 \\
\hline & & - Livestock Insurance Policy and Agriculture and Livestock Insurance Regulation \\
\hline & & - National Land Use Policy, 2012 \\
\hline
\end{tabular}

${ }^{1}$ All the laws, policies and rules are under the Interim Constitution of Nepal, 2007, the fundamental law of land.

\subsubsection{Strengths and Opportunities}

The APP identified livestock as one of the four priority outputs, and planned to raise its share in the AGDP to 45 percent, through a targeted livestock annual growth rate increasing to 6.1 percent for the plan period from 2.9 percent previously.

(a) The APP introduced the vision of commercialization of agricultural sector, including the LSS [10].

(b) The APP emphasized the promotion of private sector investment in livestock, as livestock output is assumed to be largely demand-driven and dependent on private sector activities.

(c) With regard to public sector investment in the livestock sector, APP accorded first-order priority to transportation followed by irrigation and research and extension. The APP estimated public sector investment in the livestock subsector over 7 years (1997-2004) at 5 billion Nepalese rupees (NPR), which was almost fully met by the government's budget allocation.

(d) The APP planned to use the livestock sector to aid regional balance and gender mainstreaming.

(e) The APP recognized livestock as a high-value product and acknowledged the need for import substitution.

(f) To achieve growth in livestock business, the APP recommended several policy reforms, including the removal of subsidies in livestock processing and marketing, resolution on the privatization of the Dairy Development Corporation (DDCN), enforcement of standards, establishment of a market information system, introduction of seasonal pricing of milk, and removal of restrictions on the movement of livestock commodities [3].

(g) In the poultry business, an annual growth of 5.37 percent was achieved against the APP target of 5.1 percent [3]. 
(h) The APP exempted fresh milk and yoghurt from the Value Added Tax (VAT), making them cheaper to consumers and helping the dairy industry expand.

(i) The APP's long-term vision recognizes the need of formulating policy in view of recent developments including the liberalized economic environment, increased role of private sector, Nepal's Millennium Development Goal commitment, and Nepal's commitment to the WTO and regional trading arrangements.

\subsubsection{Weaknesses and Threats}

(a) In most cases agriculture and livestock related policies have not been implemented effectively because of various factors, including limited human resources and implementation capacity, lack of supportive legislation and monitoring and evaluation, poor coordination and weak planning [3].

(b) The APP's livestock sector strategy laid emphasis on milk and meat production, animal nutrition (specifically, nutritious fodder supply), and health and marketing, while it did not prioritize wool and pashmina, despite the large export manufacturing industries based on these two products. The threats of market domination from Tibetan wool producers that supply wool to the Nepali pashmina and carpet industry continue to exist, as the current amount of pashmina and sheep wool produced in the country is not sufficient or of acceptable quality for producing exportable carpet and pashmina to even meet the 8 percent minimum local wool requirement stipulated by the WTO's rules of origin (RoO). Scattered herders in the mountains produce wool, but there is no aggregation into viable-scale lots, and there is little or no primary processing to connect the value chain. As a result, raw wool is sold into Tibet, where primary processors raise the value significantly through simple removal of coarse hair, washing and bulk-packing, and the Tibetan traders subsequently sell it back to Nepal at about 10 times the price. To address this problem, the new policy should promote processing pashmina and sheep wool within Nepal by collecting it from small, scattered herders.

(c) The APP's actual achievement of targeted annual growth rates in the milk and meat areas fell short, as up to $2003 / 04$ they amounted to 2.77 percent and 2.87 percent, respectively against the targets of 4.2 percent and 4.5 percent [3].

(d) The APP did not address the impact of the existing legislation on the APP implementation, nor did it propose specific legislative changes.

(e) APP did not take into consideration climate change and its effect on livestock activities.

(f) There is a lack of policy consistency and clarity. Not laying a substantial emphasis on the privatization of the DDCN implies that the APP recognized the importance of promoting a level playing field between the DDCN and the private sector. Hence, in view of the privatization of the Pokhara Milk Supply Scheme, a project under the DDCN, in June 2004 in order to comply with the conditions associated with the ADB Community Livestock Development Project loan, new livestock-related policy should make a clear policy decision on whether to privatize DDCN.

(g) The DDCN's role as the price-setter and controller in the dairy business instead of market mechanisms goes against the APP spirit. Set prices do not reflect geographic location 
differences, cross-border prices, general business cycles, and the impact of rising costs, wages, utilities, and taxes. Donor agencies and analysts have concluded that the government fixing of producer and retail prices is a major detriment to dairy development in Nepal. This reiterates the need for policy reforms as part of the new national livestock policy.

(h) Although APP's vision of commercializing the livestock sub-sector is consistent with the Ninth Plan, Tenth Plan and NAP-2004, little has been done, except for the implementation of the Pocket Package Strategy (PPS) approach. The concept of contract farming proposed in these five-year plans can be applicable to livestock subsector also, and can be proposed in the new livestock policy.

(i) The APP posted hardly any progress in implementing programs on slaughterhouse and meat inspection. The House and Meat Inspection Act, 1999 and Slaughter House and Meat Inspection Rule, 2001 are yet to be implemented at the national level.

(j) APP policy to exempt livestock and livestock products (including poultry products, feed and feed ingredients) from local taxes as well as to remove barriers to livestock commodity movements was not fully implemented. Local bodies levying taxes on livestock products have often inhibited such products' free movement. Therefore, the new livestock policy should incorporate a categorical policy on implementing such tax exemption provisions.

(k) The APP did not exempt dairy products such as cheese, paneer and ice cream from the value-added tax. To promote the commercial potential of dairy products, the new livestock policy should consider VAT exemption on them.

In the nutshell, the performance of the APP was mixed. Combined with the changed internal and external context, this led the Nepal Government to formulate a new long-term strategy for Nepal, namely the Agriculture Development Strategy (ADS) [3].

\subsection{National Agriculture Policy (NAP), 2004}

While the APP was being implemented, National Agriculture Policy, 2004 was introduced. The NAP, 2004 adopts a long-term vision oriented towards transforming the current subsistence-oriented farming system into a commercial and competitive one. The NAP aims to contribute to ensuring food security and poverty alleviation. Its objectives are:

(a) To increase agricultural production and productivity,

(b) To develop the basis of a commercial farming system and make it competitive in the regional and world markets, and

(c) To conserve, promote and properly utilize natural resources, as well as the environment and bio-diversity.

The policies of the NAP provided for achieving its objectives include:

(a) to ensure the needs of farmers (I) with access to resources; and (II) with comparatively less access to resources,

(b) to provide special facilities by classifying farmers into (I) those having less than half a hectare of land and lacking irrigation facilities; and (II) those belonging to dalit (so-called untouchable) and 
utpidit (downtrodden, underprivileged) classes and other marginal farmers and agricultural workers.

The policy area coverage of the NAP is comprehensive, and it provides a participatory method to ensure the involvement of the stakeholders at the concerned level (village, district, region or nation) in the process of formulating, monitoring and evaluating plans connected with the agricultural sector.

The NAP provides for the formation of a National Agricultural Development Board at the national level, and Agricultural Development committees at national, regional, district and VDC levels. The NAP aims to make Village Development Committees (VDCs) and District Development Committees (DDCs) responsible for the formulation, implementation, monitoring and evaluation of plans in accordance with the Local Self-governance Act, 1997. The Policy gives special priority to a set of high-value agricultural products, and seeks to develop commercial and competitive farming systems by a gradual extension of livestock insurance programs and organic farming.

Overall, the NAP, 2004 has the merit of being decentralization-based, friendly to small-holder farmers of livestock, and inclusive of untouchables, marginalized groups and poor communities. Our specific policy suggestions vis-a-vis the existing strengths of the NAP, 2004 from the livestock point of view are given in Table 2.

Table 2. Outcomes of SWOT analysis of National Agricultural Policy.

\begin{tabular}{|c|c|}
\hline Strengths (Positive Provisions, Potentials) & Weaknesses (Gaps, Shortcomings): Areas of Improvement \\
\hline - Identification of priority areas of agriculture in Nepal & - Identification of too many areas as priority impedes effective implementation \\
\hline \multirow[t]{2}{*}{$\begin{array}{l}\text { - Developing integrated National Agricultural Resource Centers } \\
\text { capable of operating survey/surveillance and laboratory services for } \\
\text { diagnosis of livestock disease, soil analysis, seed certification, and } \\
\text { crop protection, and providing capacity development training to } \\
\text { entrepreneurs, business persons, cooperative workers and } \\
\text { agriculture activity workers. }\end{array}$} & $\begin{array}{l}\text { - The institution responsible for developing National Agricultural Resource } \\
\text { Centers and procedure for them should be specified }\end{array}$ \\
\hline & $\begin{array}{l}\text { - Capacity development training authority and systems should be specified and } \\
\text { put in place. }\end{array}$ \\
\hline $\begin{array}{l}\text { - Provisions on livestock and crop insurance and extension of } \\
\text { livestock insurance program }\end{array}$ & $\begin{array}{l}\text { - Legislation, responsible institutions and implementation modality need to be } \\
\text { developed for effective livestock and crop insurance. }\end{array}$ \\
\hline \multirow[t]{2}{*}{$\begin{array}{l}\text { - Policy on commercializing different agro-products and attracting } \\
\text { investors in agriculture }\end{array}$} & $\begin{array}{l}\text { - Agro-products to be prioritized for commercialization and investment should } \\
\text { be identified based on market potential and specific strategies for them } \\
\text { should be developed, augmenting the agro-based commodities listed in the } \\
\text { National Trade Integration Strategy (NTIS)-2010. }\end{array}$ \\
\hline & $\begin{array}{l}\text { - There should be policy incentives and programs to promote forage crops to } \\
\text { ensure uninterrupted availability of feed and fodder to livestock. The forage- } \\
\text { manure-crop nutrient cycle should be promoted to supply manure essential } \\
\text { for agricultural crops. }\end{array}$ \\
\hline $\begin{array}{l}\text { - Policy to systematize and strengthen livestock quarantine services to } \\
\text { raise the quality of livestock products and market confidence in them }\end{array}$ & $\begin{array}{l}\text { - A system and institutional arrangement for livestock quarantine services } \\
\text { should be put in place to limit disease outbreaks and market impacts. }\end{array}$ \\
\hline
\end{tabular}




\subsection{Agro-Business Promotion Policy (ABPP), 2006}

The ABPP, 2006 aims at diversification, service delivery and private sector involvement to transform agriculture from subsistence to commercial farming. The policy aims to reduce poverty by encouraging production of market-oriented and competitive agro-products and promoting internal and external markets. The policy's specific measures include public-private partnership in services delivery and in infrastructure for storage, marketing and processing. Such measures have been successful, and could be replicated with further investments (Table 3 ).

Table 3. Outcomes of SWOT analysis of Agro-Business Promotion Policy.

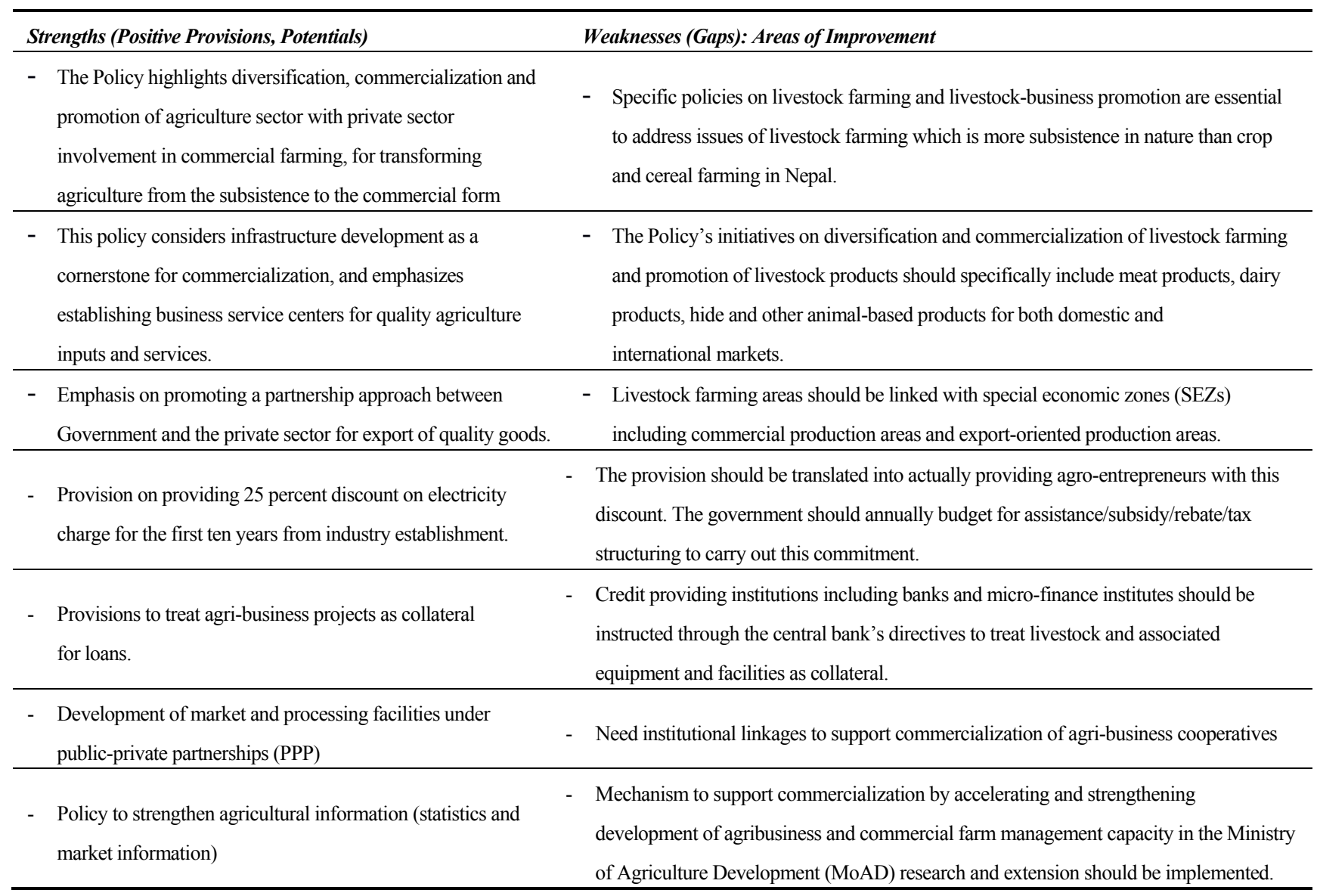

\subsection{Forestry Sector Policy, 2000 (Forest Policy, 2000)}

The Forestry Sector Policy, 2000 is relevant to the LSS, as farmers use forests to graze livestock and to collect fodder to feed livestock.

\subsubsection{Strengths and Opportunities (Positive Provisions, Potentials)}

I The policy simplified the process of handover of institutional as well as group leasehold forestry to Community Forestry User Groups (CFUGs) and has stressed integration of the leasehold forestry program to local community development. 
II The Policy recommended commercial management for forests in larger blocks in Terai and Inner Terai districts. It provided for the Operational Forest Management Plan (OFMP), a plan consistent with the priority objectives of the erstwhile APP.

III The Policy aims to base livestock quantities on the amount of fodder production and highland pasture so as to improve forest management and increase the production of fodder by community efforts. The Policy calls to immediately design an integrated national forage development program and an appropriate institutional arrangement for its implementation in order to complement the Master Plan for the Forestry Sector and the APP.

\subsubsection{Weaknesses and Threats (Gaps, Shortcomings)}

I Disputes on use of forest resources including the fodder and grazing land (range-lands) should be properly resolved through collaborative forest management mechanisms so that livestock farming can make use of appropriate grazing land.

II Integrating livestock rearing into community forestry is needed to share forest resources and address the shrinking size of grazing lands.

III In the livestock, agriculture and forestry sectors, efforts should be made to bridge the gap in national support for Clean Development Mechanism (CDM) projects developed to address climate change.

IV Livestock management should be initiated in close coordination with the mechanism of handing over forests to community forest user groups (CFUGs) and using community forest resources.

$\mathrm{V}$ The proposed integrated national forage development program and institutional arrangement for its implementation should now be aligned not with the APP but with the forthcoming Agriculture Development Strategy, which has identified feed shortage as one of the main constraints for increasing livestock production.

VI The livestock projects should be strengthened to create awareness of the farmers in cultivating forage and pasture.

\subsection{National Micro-Finance Policy, 2005}

The National Micro-Finance Policy, 2005 mainly aims at helping to alleviate poverty through micro-financial services, and targets the agricultural and livestock sectors, among others.

\subsubsection{Strengths}

I Provides for micro-finance facilities to agriculture sector and allows for group guarantees

II Sees agriculture as a priority sector for micro-finance

\subsubsection{Weaknesses}

I It is highly essential to have separate policies governing micro-finance for the livestock subsector instead of a blanket agriculture-related one, as this subsector has its own salient features that vary substantially from other subsectors of agriculture 
II There is the need for according specific priority to livestock subsector micro-finance by making it mandatory not only for micro-finance institutes but also for commercial banks to allocate/ earmark at least a specific fraction, such as one third (1/3), of the total agricultural loans/ investments in the livestock business.

\subsection{Dairy Development Policy, 2007 (2064 BS)}

The policy (DDP) envisions investment in the income and employment generating and poverty-alleviating dairy business. To achieve this vision, it has adopted the policy of providing pasture (grazing land) and cattle feed year-round.

\subsubsection{Strengths}

The DDP encourages concerned organizations to provide collateral-free soft (concessional) loans, group loans and technical assistance to farmers, particularly women and underprivileged communities, with a view to promoting livestock farming. The DDP seeks to mobilize farmers' cooperatives to promote livestock insurance service extension, and provides that the Nepal government may subsidize the premium on livestock insurance obtained by farmers through their cooperatives and groups. Accordingly, the Nepal Government, in its national budget speech-2014/15, has announced a 75 percent subsidy on the livestock insurance premium [11].

I To ensure quality dairy production, the DDP has entrusted the Department of Livestock Service with the responsibility to provide technical services, manage cattle-feed and livestock health training, and minimize costs.

II The Policy is based on a long-term vision to encourage participation of public, private and cooperative sectors in dairy production.

III A DDP objective is to increase production and productivity of milk in rural areas which helps alleviate rural poverty.

\subsubsection{Weaknesses}

I To assure micro finance lenders and banks of the security of collateral-free loans, there should be provisions for community-based group-guarantee and group-monitoring of dairy borrowers.

II Incentives to disadvantaged communities will not materialize until social laws and practices effectively erase the old social stigma against using milk and dairy items produced by so-called low-caste people. This effort should coordinate with other social laws and law-enforcing agencies including police and civil servants.

III A large-scale livestock insurance system is yet to be developed. Subsidies should be coordinated with the Livestock Insurance Policy, and there is a need for a setting and monitoring mechanism in this regard.

IV Resource centers of improved livestock (dairy animal) breeds should be developed.

$\mathrm{V}$ A mechanism to ensure participation of smallholder farmers (backward linkage) at all stages of the value chain to retail products is essential. 
VI Access of rural farmers to livestock support services and loans should be increased through district livestock offices and bank and micro-finance institutes.

\subsection{Agriculture Bio-Diversity Policy, 2007}

The Agriculture Bio-diversity Policy resulted from Nepal's accession in 1993 to the International Convention on Biological Diversity (CBD)-informally known as Convention on Biodiversity - adopted at the Earth Summit in Rio de Janeiro, Brazil in 1992. This policy is in accordance with the objectives of NAP-2004 to protect, promote and utilize bio-diversity and to promote ecological balance. It intends to lead to benefit from protection and utilization of genetic resources for food security, livelihood security and poverty reduction. Livestock genetic improvements enabled by diversity are expected to contribute to increased productivity.

\subsubsection{Strengths}

The Policy has the overriding objective to protect, promote and utilize genetic resources and protect biodiversity for sustainable agricultural development coupled with food and nutritional security.

\subsubsection{Weaknesses}

I Regulation for research and experimentation on Nepalese bio-diversity and genetic resources of livestock is yet to be developed and implemented.

II A system for registration and allocation of agro- and livestock biodiversity should be developed.

\subsection{Trade Policy, 2009}

The Trade Policy is formulated to address issues of international trade dynamics such as affiliation with the regional and multilateral trading system, expansion of bilateral free trade areas, simplification of trade procedures, development of new border transit system, sanitary and phyto-sanitary (SPS) measures, and managing technical barriers to trade (TBT), which could contribute towards sustaining the export trade. This policy aims to support economic development and poverty alleviation through enhanced development of the trade sector. Nepal is a chronic trade-deficit country, having a trade imbalance of more than national budget in the fiscal year 2013/14.

\subsubsection{Strengths}

The Policy lays emphasis on commercial livestock farming and the promotion and supply of improved breeds. The Policy offers capital and technical assistance for the commercial farming of animals to ensure supply and export of high-quality rawhide and skins.

\subsubsection{Weaknesses}

I Nepal's international (export) trade of livestock products and animal-based goods makes it mandatory to develop specific programs and infrastructure/facilities on sanitary and 
phyto-sanitary measures in compliance with WTO's Agreement on Trade Related Aspects of Intellectual Property Rights (TRIPS) and World Intellectual Property Organization (WIPO)'s Conventions, to which Nepal is a party [12-15].

II National policies and programs to develop an export led production zone or processing zone with market link are essential.

III National policies and programs on initiating effective international marketing and competitiveness-enhancement for Nepali livestock-related products should be specifically developed to address the export requirements specific to livestock, including proper packaging and advertising policies to address the sanitary and hygienic concerns of foreign consumers.

\subsection{Climate Change Policy, 2011}

The Climate Change Policy, 2011 is based on Nepal's ratification on November 1, 1993 of the United Nations Framework Convention on Climate Change (UNFCCC) negotiated at the UN Conference on Environment and Development (UNCED) or the Earth Summit held at Rio de Janeiro, Brazil in June 1992 [16]. Nepal also acceded to the Kyoto Protocol (KP) which is an international agreement linked to the UNFCCC, on 19 September 2005. Nepal also adopted a National Adaptation Program of Action (NAPA), 2010 and Local Adaptation Program of Action (LAPA), 2011 for climate change adaptation $[10,17,18]$.

The main goal of the Climate Change Policy, 2011 is to improve livelihoods by mitigating and adapting to the adverse impacts of climate change, adopting a low carbon emissions socio-economic development path, and meeting the spirit of the country's national and international agreements related to climate change.

\subsubsection{Strengths}

Sustainable management of forests, agro-forestry, pasture, rangeland, and soil conservation that can address the impacts of climate change are in urgent need and are identified as potentials to be prioritized and implemented. Climate adaptation implementation needs to be linked with socio-economic development and income-generating activities to the extent possible.

\subsubsection{Weaknesses}

Despite advocating sustainable management of pasture and rangeland, the Climate Change Policy-2011 lacks specific strategies and policies in this area. Livestock-specific policies and programs are essential, as intensification of climate change effects adversely affects biodiversity, diminishes and damages grazing lands, and puts livestock at great risk. Policy should also specifically address the needs of livestock development and income-generating activities relating to livestock.

\subsection{Rangeland Policy, 2012}

The Policy defines rangeland as natural pasture land, grassland and shrub-land. It aims to increase productivity by improving forage/grass productivity, to protect livestock farmers' traditional rights for 
pasturing livestock in community rangeland and forest, and to determine stocking density to minimize competition between grazing domestic and wild animals.

\subsubsection{Strengths and Opportunities}

The Policy seeks to secure the facilities traditionally enjoyed by livestock farmers using range-lands located within community forests. The Policy identifies provisions to collect and conserve the green forage (grass) during the rainy season and winter and dry seasons in order to ensure continuous supply of cattle feed round the year. The Policy seeks to determine livestock density on the basis of capacity of the rangelands for minimizing the grazing competition and pressure of both domesticated and wild animals, and imposes charges or penalties on cattle for using rangeland with the goal of limiting unproductive cattle on the rangeland.

\subsubsection{Weaknesses and Threats}

I There is a need for integrating livestock rearing into community forestry to share forest-resources and meet the threat of shrinking size of grazing lands.

II Institutional arrangements and collaboration of government with livestock farmers and community forest users at the local level are essential to ensure a continuous year-round supply of cattle feed.

III The rangeland charge-important as an income-generating source for the rangeland management - should be well streamlined and managed.

IV The rangeland charge should serve as a sufficient control measure to discourage use of rangeland by unproductive cattle, as the owners of such cattle would not let them graze in the rangeland; it is impractical and often cumbersome for the rangeland officials to directly identify productive and unproductive cattle.

\subsection{Livestock Insurance Policy and Agriculture and Livestock Insurance Regulation (2013)}

Livestock insurance is extremely important, as livestock husbandry is risky, particularly for small and low-income farmers who face financial ruin in case of theft, injury, illness or death of an animal. According to DOLS, premature mortality is about 2 percent to 3 percent per annum for cattle and buffalo and considerably higher for small ruminants and pigs. Livestock insurance helps livestock farmers to cope with such risks, and facilitates farmers' access to finance by increasing their creditworthiness.

Although general insurance was introduced in Nepal in 1937 after the establishment of Nepal Bank Ltd, the country's first commercial bank, and the National Insurance Corporation was established in 1967 [13], livestock insurance began only in 1987 in form of livestock credit or micro-finance guarantee insurance against animal mortality and loss. In Nepal, many organizations provide livestock insurance services on a limited scale; they include the Small Farmers' Development Bank (SFDB), Micro-Finance Institutions (MFI), Community Livestock Development Projects (CLDPs) sponsored community-based organization (CBOs) and Financial Intermediary Non-Governmental Organizations (FI-NGOs) which are not regulated by the Insurance Board (IB), the national-level regulating body. 
This gap should be addressed by a proper policy mechanism. In recognition of the need of systematizing livestock insurance, Nepal introduced Livestock Insurance Regulation and a Livestock Insurance Policy. The Livestock Insurance Regulation under the Insurance Board aims at encouraging financial institutions to finance more agricultural projects, as most financial institutions abstain from extending loans and advances to livestock and agricultural projects in the absence of proper insurance coverage. The Agriculture and Livestock Insurance Directive makes it obligatory for non-life insurance companies to issue insurance policies on livestock, crops and poultry. Table 4 outlines the SWOT analysis of National Livestock Insurance Policy.

Table 4. SWOT Analysis of Livestock Insurance Policy.

\begin{tabular}{lll}
\hline \multicolumn{1}{c}{ Strengths } & \multicolumn{1}{c}{ Weaknesses } \\
\hline $\begin{array}{l}\text { Policy to promote livestock and crop insurance } \\
\text { for encouraging financial institutes to invest }\end{array}$ & $-\quad$ There should be specialized insurance companies licensed by the Insurance Board to provide \\
more on livestock and crop projects. & crop and livestock insurance policies. \\
& The number of microfinance institutions, agriculture cooperatives and financial Non \\
& Government Organizations (NGOs) that provide livestock and crop insurance as part of their \\
& credit-plus program to their beneficiaries should be increased. The ceiling on the amount of \\
& insurance they may provide should be raised from the current limit of Nepalese Rs $100,000$. \\
\hline
\end{tabular}

\subsection{National Land Use Policy, 2012}

The Policy aims to encourage optimal use of land for agriculture by classifying the country's land territory into seven land use categories - agricultural, forest, residential, commercial, public, industrial, and others. Land in the agriculture category is for agricultural cultivation, livestock farming, and tree plantation. The Policy also aims to increase agricultural productivity by systematizing land fragmentation and by adopting a land pooling system. The goal is to encourage commercial, cooperative and contractual farming. The SWOT analysis of National Land Use Policy is outlined in Table 5.

Table 5. SWOT Analysis of National Land Use Policy.

\begin{tabular}{ll}
\hline \multicolumn{1}{c}{ Strengths } & \multicolumn{1}{c}{ Weaknesses } \\
\hline - Policy to allocate land for agricultural purposes including livestock farming & $\begin{array}{l}\text { For all these policies to be effectively implemented there is } \\
\text { an } \quad \begin{array}{l}\text { imperative need of a separate Land Use Act that } \\
\text { provides adequate legislative backing. }\end{array} \\
\text { - The Policy also aims to increase agricultural productivity by controlling land }\end{array}$ \\
$\begin{array}{l}\text { fragmentation, systematizing land-pooling activities, and encouraging } \\
\text { commercial, cooperative and contractual farming }\end{array}$
\end{tabular}

\subsection{Breeding Policy, 2011 (2068)}

The Policy aims at increasing productivity of milk, meat and eggs and hence increasing farmers' income through improvement of livestock and poultry. 


\subsubsection{Strengths and Opportunities}

The policy has set goals of utilization, conservation and improvement of genetic resources and capabilities of livestock and poultry and hence achievement of increasing productivity.

\subsubsection{Weaknesses}

I There is a need to exploit potentials for breed improvement and increasing livestock productivity.

II There should be a policy and implementation mechanism on development of livestock (and poultry) resource centers through public-private partnership.

III Programs should be urgently initiated to conserve indigenous breeds which are in danger of extinction.

IV Policy and programs to promote breeding of productive livestock (genetic resources) are needed as a part of implementation of agreements from the New Earth Summit 1992 (on livestock genetic resource conservation and their improvement).

\subsection{Animal Health Program Implementation Procedure, 2013 and Animal Health and Livestock}

Services Act, 1999

The Animal Health Program Implementation Procedure, 2013 was introduced in line with the Animal Health and Animal Service Act, 1999 and its related Regulation.

\subsubsection{Strengths and Opportunities}

The policy rightly aims at promoting production, distribution, consumption and export of healthy livestock and making animal-health related programs more effective, as these functional areas are crucial in livestock management.

\subsubsection{Weaknesses}

There is a need to develop policy and procedures to protect livestock from emerging internationally endemic diseases such as swine flu and foot-and-mouth disease, which should be explicitly tied to implementing the WTO Agreement on Sanitary and Phyto-sanitary (SPS) Measures [12,13,15].

\subsection{Labor Policy, 1999, and Child Labor Act, 2000}

Nepal, a member of the International Labor Organization (ILO), has so far signed 11 ILO conventions $[4,19]$. Hence, it should make its labor policy and practices fully compliant with its commitment to international labor standards and practices. The Labor Policy, 1999 in compliance with the Child Labor Act, 2000, bans use of child labor in economic activities. The policies and provisions also have bearing on livestock management. 


\subsubsection{Strengths and Opportunities}

Policies to ban forced or voluntary use of child laborers in economic or business activities are identified. By implication, the use of children is restricted in the risky work of herding big ruminants.

\subsubsection{Weaknesses}

The Labor Policy needs to specifically address the problem of the widespread use of child labor in livestock farming.

\subsection{Birds Rearing Policy, 2011}

The policy was issued within the framework of National Agriculture Policy (NAP), 2004 and Agri-business Promotion Policy, 2006. The policy covers the poultry business, encompassing chickens, cocks, hens, ducks, turkeys, quails and other local bird species.

\subsubsection{Strengths and Opportunities}

I The policy is compliant with key agricultural national documents including the supplementary to the National Agriculture Policy (NAP), 2004 and Agri-business Promotion Policy, 2006.

II It plans to make the poultry business more productive, competitive and sustainable by improved quality of chicks through well-managed hatchery and rearing as well as by systematizing distribution of poultry products.

III The policy envisages programs to base bird rearing and poultry businesses on comparative cost advantages and production potentials.

IV The policy is consistent with the national policy thrusts of public-private partnership and environment protection as far as its implementation plans are concerned.

\subsubsection{Weaknesses and Threats}

The policy has not spelled out plans and mechanisms to fight the consequences of sudden outbreaks of bird flu and other diseases that have devastated Nepalese poultry in recent years. Such policies and functional strategies should be in accordance with the WTO Agreement on Sanitary and Phyto-sanitary Measures.

\subsection{Approach Paper to 13th Plan and Agriculture/Livestock Development Policies}

After 2007, different stakeholders in the Government of Nepal (GoN) and society at large increasingly perceived that the APP — viewed in a new national and international context - had not been successful in achieving its main targets and that there was the need of a new long-term strategy, which in 2012 resulted in the formulation of the Agricultural Development Strategy [3]. The agricultural sector development policy in the ASOPs of the Approach Paper to 13th plan (2013/14-2015/16) has made provisions for the livestock sub-sectoral development by including it in objectives, strategies and operating policies. The agricultural sector objectives set in the Approach Paper to the 13th Plan are 
I To increase the production and productivity of crops and livestock products,

II To make crops and livestock products competitive and commercial,

III To develop and disseminate environment-friendly agro-technologies to minimize the adverse impacts of climate change, and

IV To conserve, promote and utilize agro-biodiversity

The sectoral strategies for achieving the objectives are directed towards

I Promoting commercialization and diversification of agriculture and livestock

II Developing crop and livestock industries and enhancing their product quality

III Encouraging youths to take up commercial farming as a prestigious profession

IV Promoting agricultural and livestock marketing, and

V Promoting the results-oriented application of technologies in the sector; while many of the 46 operating policies set in line with the eight priorities or strategies are generally related to the overall agricultural sector, some others are specific to the livestock subsector:

I to expand promoting campaigns regarding artificial insemination and fodder and forage plantation,

II to develop rural infrastructures such as agro-roads, electricity, and communications,

III to develop agricultural marketing network including livestock wholesale markets and hat bazaars (open-air retail markets), and expand access of livestock information at local levels,

IV to develop technical manpower for agricultural sector and provide entrepreneurship and skill development training required for agro-business,

$\mathrm{V}$ to encourage production of high quality seeds, high-yielding breeds and vaccination, and to develop bio-pesticides to treat animal for parasites,

VI to make provisions for livestock insurance, concessional agricultural loans, subsidy on livestock related industrial equipment and tax rebate on trade to small and marginalized farmers, entrepreneurs and business people,

VII to promote contract and cooperative farming with involvement of private entrepreneurs and cooperative sectors,

VIII to establish agriculture and livestock extension centers under the local bodies at each VDC,

IX to strengthen livestock related laboratories, and

$\mathrm{X}$ to provide integrated agricultural and livestock services and make effective involvement of national and international non-governmental organizations, universities and local bodies in providing such services.

The TP Approach Paper - although the most recent of the three major policies and policy-documents we have been considering - failed to make any mention of either of the other two, the NAP, 2004 and ABPP, 2007. No plan can be implemented in isolation without coordinating with other existing policy frameworks and implementation mechanisms. Hence, it is desirable that the 13th Plan formulates and executes plans and policies in pursuance and compliance with the previously issued and/or existing national policies as starting points for revision. Even though the Approach Paper envisages 
commercializing the livestock business and making this subsector competitive, lack of coordination and collaboration with other subsectors of agriculture as well as with existing agriculture-related policies is likely to handicap the accomplishment of the purpose. For instance, the National Agriculture Policy, 2004 has the policy to promote programs on improved livestock production and productivity, controlling livestock-related diseases and systematizing livestock quarantine services; but the Approach Paper has established no explicit linkage with such existing frameworks.

\section{Critical Cross-Cutting Concerns Facing the Livestock Subsector}

The ASOPs in the Approach Paper to the 13th Plan (FY 2013/14-2015/16) also recognized the national policies on poverty alleviation, human resource development, labor and employment, sustainable and balanced development, environment and climate change, gender equality and inclusion and disaster management as cross-sectoral policies. Nepal's livestock subsector relates closely to several of these critical issues, which demand serious consideration in LSS policy-making initiatives.

\subsection{Sectoral Contribution to Regional Balance and National Trade Balance}

The LSS contributes to within-country regional balance in Nepal [10]. Compared to the southern belt of Terai and the valleys and towns in the Hill region, the potential of industrial businesses is almost non-existent in the Mountain region located in the country's north, where livestock businesses display the most potential to contribute to economic activity. The LSS is also immensely important for its tremendous potential to contribute to national goals of export promotion, trade deficit reduction, poverty reduction and import substitution.

\subsection{Gender Mainstreaming and Child Labor}

The Platform for Action of the World Conference on Women held in Beijing, 1995 provided an impetus to address gender inequality, and the Government of Nepal formulated a national plan of action to implement 12 critical areas of concern in line with the UN Millennium Development Goals (MDGs), including women's poverty, access to education, health services, participation in decision making, and vulnerability to violence [20,21]. The Interim Constitution of Nepal, 2007 provides that the state shall not discriminate in any form against women and shall pursue a policy of encouraging maximum participation of women in national development [9]. The ADB-assisted Third Livestock Development Project (TLDP), 1997 and Community Livestock Development Project (CLDP), 2004, for Nepal also accorded high priority to gender aspects in livestock. Nepal has ratified two relevant international conventions, Elimination of All Forms of Discrimination against Women and UN Declaration against Discrimination of Women and Men. Nepal's commitment to non-discrimination, gender equality, and social justice at national and international levels should be reflected in its national policies and practices, and hence gender is a critical factor in the formulation of the new national livestock policy.

The LSS plays a predominant livelihood role in the hills and mountains, and given that some 70 percent of the work in livestock farming is performed by women [9], the livestock business possesses tremendous potential to promote gender equality via empowerment and inclusivity of women and can 
contribute to national gender mainstreaming initiatives. However, rural women's dominant role in livestock activities is so far limited to livestock rearing, including fodder/ forage collection, feeding, herding, breeding and animal-health care. Women are largely denied any role in and access to economic returns from the livestock. Instead, men in the family solely handle the sales of livestock outputs including milk, wool, manure, and the livestock themselves and hold the proceeds. Gender balance is therefore a critical issue which should be addressed in the National Livestock Policy. Migration of men from rural areas has resulted in growing feminization of rural households, which increases the burden to women who also face vulnerability due to lack of access to financial and educational resources and restriction on their social roles and mobility.

Use of child labor is common and widespread in livestock farming, particularly in collection of feed and fodder and in grazing. Use of children in livestock farming-whether voluntary or imposed as their familial obligation-deprives them of the opportunity to go to school, and also puts them at physical danger in handling and herding large cattle.

\subsection{Gaps between Policy and Implementation}

National policy is a broad course of action adopted by the government in pursuit of its objectives. Nepal has already a rich body of policies in favor of agriculture [3]. The National Agriculture Policy and the Approach Paper to the 13th Plan emphasize the central role of agriculture. Nevertheless, formulation of some important policies has been excessively delayed. For example, breeding policy remains under review though its improvement was initiated more than 50 years ago. The gaps in policy and in the implementation of existing policies are outcomes of

I Lack of supportive adequate legislation (acts), rules and regulations for credible enforcement,

II Inadequate resource allocation,

III Ineffective coordination,

IV Irregular and weak policy and program monitoring and evaluation,

$\mathrm{V}$ Lack of climate change monitoring,

VI Limited human resources and implementation capacity, and

VII Lack of continuity in leadership (short tenures of ministers and secretaries).

\subsection{Gaps in Planning Process}

The ADS (2012) identified the following gaps in the planning process [3]:

I Poor data base for agriculture sector, especially in the areas of productivity, inputs, trade, seeds, improved breeds and agribusiness.

II The periodic plans do not cover programs/projects to the implemented through private sector, community-based organizations (CBOs) and non-government organizations (NGOs); the plans very much concentrate on programs to the implemented by the government only.

III There is no system of output and impact monitoring and evaluation.

\subsection{Pro-Poor Policy and Poverty Reduction}


Proper LSS development is critical to poverty reduction, the overriding goal of all national plans and policies in Nepal. With almost three out of every four Nepali households and almost every household in Mountain and Hill rural areas involved in livestock rearing [22], improved performance in livestock activities could be instrumental in Nepal's national bid to reduce poverty. At the same time, livestock vulnerability resulting from poverty, climate hazards, declining ecosystem services and socioeconomic inequality leads to low yields, indebtedness, and worsening poverty among poor livestock farmers with small holdings and no other socio-economic backups. There is an imperative need for making the national livestock policy pro-poor. The livestock subsector holds tremendous potential for bringing communities of marginalized, underprivileged and indigenous groups as well as so-called untouchables into the national mainstream, since many of these groups are heavily reliant on livestock.

\subsection{Political Restructuring}

The Approach Paper to the 13th Plan aims at promoting good local governance and empowering local bodies politically, financially, administrative and judicially in federal structure. Obviously, the livestock subsector and policy cannot function and thrive unless they are matched with Nepal's state structure. Nepal is committed to restructure its unitary, highly centralized government to form a federal, decentralized democratic system. Policies governing the livestock subsector are to be enforced at both federal (central) and state levels, for which coordination and consistency are indispensable. The federal or central government will have responsibilities for designing and implementing national policies, and the state or regional, district and city level governments have to manage local affairs concerning administration, law enforcement, and development under the federal national policies, regulations and mandates [23].

\section{Livestock Policy and Vulnerability}

The vulnerability of Nepal's livestock subsector includes livelihood vulnerability and climate-change vulnerability.

\subsection{Livelihood Vulnerability}

Livestock is an important resource of livelihood in Nepal [22]. The threats of livelihood vulnerability to livestock farmers in Nepal are mainly due to small holdings, poverty, and socioeconomic marginality. A majority of farmers in Nepal have poor resource endowments, small land holdings and lack of access to adequate land, low bargaining power, and weak risk bearing capacity. For smallholders, losing livestock has a great impact and lasting effect on livelihood so that livestock sickness and mortality could even trigger chronic poverty. High vulnerability and reduced livelihood options has increased off-season migration to India and more distant countries, which has increased the risks of indebtedness of poor families and put additional burden on women, children and elder population to cope [24].

Despite its crucial importance, Nepal's policies did not pay adequate attention to livelihood vulnerability in agriculture sector. For instance, Cameron (1998) found that the 20-year APP failed to 
grasp the nature of livelihood inequalities and there was no targeting of livelihood vulnerable people by economic, social, geographical or age factors $[25,26]$.

\subsection{Climate Change Vulnerability}

Climate change impacts on the overall livestock system are mainly due to the changed water resource supply, forest health, soil health, land use, and human settlement and migration patterns. Climate change impacts in Nepal have added new dimensions of challenges to many sectors of natural resource management. More severe impacts have been observed in the rural and remote areas where the livelihoods of people are based on subsistence agriculture with limited livelihood options. People are vulnerable to extreme weather events, have poor access to information and lack resources to cope with and recover from climate-related disasters.

The impacts of climate change are not evenly distributed between different communities. Poor and marginalized communities, who often live in disaster-vulnerable areas with limited information, limited livelihood options and low adaptive capacity, are most vulnerable to climate change [25,27]. Similarly, women are on the front line of climate change due to their multiple burdens to obtain livelihoods. The predicted impacts of climate change will heighten existing vulnerabilities, inequalities and exposure to hazards [28,29]. Effects of climate change tend to be more severe where people rely on weather-dependent rain-fed agriculture for their livelihoods. In rural mountain communities with limited livelihood options, adaptive capacity is low due to limited information, poor access to services, and inequitable access to productive assets. Few studies have reported on the status of rural and remote mountain areas in Nepal and on adaptation strategies in use.

Therefore, to address the climate-change vulnerability associated with the livestock subsector, there is a great need of reorientation of the livestock related national policy, restructuring of the national organizational system, enlargement of strong infrastructures and support services and promotion of gender equality with increased inclusivity and empowerment of women. The national livestock policy should address the needs of lasting sustainability, increased productivity and profitability, commercialization, expanded markets, and diversification. Nepal's National Adaptation Program of Action (NAPA), 2010 recognized agriculture and food security as one of six thematic areas [17]. Although the APP did not consider climate change issues, the 13th Plan (2013/14-2015/16) in its Approach Paper has accorded 6th priority for the promotion of mitigating and adaptive techniques and practices to minimize the adverse impacts of climate change on agricultural sector. But the same plan accorded the first (top) priority to the implementation of the NAPA, 2010 and LAPA, 2011 for poverty alleviation. And, only 6th priority has been given to designing and implementing programs related to climate change adaptation by local bodies.

\section{Rationale and Categorical Premises for a New National Livestock Policy}

Since the livestock subsector is an extremely important component of agriculture and has a nature and characteristics substantially different from other subsectors of agriculture, there is an imperative need for a separate National Livestock Policy that caters to specific needs of the livestock subsector at national, regional and local levels, so that sustainable livestock development can be fully integrated 
with related national policies, laws (acts) and other national rules and international conventions and be truly pro-poor and growth-driven.

At present, Nepal's national level policies related to the livestock subsector are scattered across different national policies. These policies should be integrated into a new National Livestock Policy. Furthermore, the policy and programs provisions in different national policies broadly relate to agriculture as a whole, whereas there is a need to have such policies and programs specifically for the livestock subsector.

There is no demarcation of objectives and strategies specific to the livestock subsector in the Plan Approach Paper. The Approach Paper in Chapter 3 deals with the sectoral development policies, of which livestock area is one of the subsectors, but makes no reference to existing agriculture-related policies. The approach paper lists 46 operating policies, but these policies are not explicitly related to the specific needs of the livestock subsector. On the other hand, as covered above, APP (1995) and the Agro-Business Promotion Plan have brought forward many pertinent issues but have not fully and adequately covered and addressed them. These problems can be resolved by formulating a new, separate national livestock policy that links the livestock subsector with other subsectors of agriculture as well as with existing related national policies.

At a time when Nepal is in the process of federating its state structures, another important issue concerning the policy on livestock subsector development is to decide whether to bring all responsibilities to livestock stakeholders (including public and private sector organizations, NGOs, livestock-farmers and service-providers) into the fold of central or federal government to avoid duplication, or to decentralize to the local levels. In view of the direction of the larger process of state restructuring, the national livestock policy should match the new federal dispensation, where states or provinces will have their own state/provincial livestock policies according to their requirements within a national policy which plays more of a coordinating role. The national livestock policy should guide and assist the local governments in framing their livestock development policies according to the location-specific needs.

\section{Policy Recommendations}

In view of the livestock-related national policies being scattered across different national policies of Nepal, there is an imperative need to formulate and implement an integrated National Livestock Policy, so that sustainable livestock development can be achieved integrated with National Agriculture Policy and other related national policies, laws, rules and international conventions. On the basis of the gaps discussed, the following general policy suggestions in regard to formulating a new National Livestock Policy may also be put forth in addition to the specific ones elucidated earlier in the review of individual policies.

Livestock policy should consider livelihood vulnerability which is potentially caused by livestock vulnerability and climate-change vulnerability. General suggestions and conclusions related to policy orientation are as follows:

I Policies on livestock insurance and corresponding institutional arrangements are essential.

II Policies and programs should provide soft loans for livestock farmers and other livestock workers including livestock health services providers. 
III National Livestock Policy should be in compliance with measures on climate change, as biodiversity loss results from intensification of climate change effects leading to degradation of pasture lands that has put livestock at great risk. There is need for capacity building on climate science and policy to inform livestock policymakers, implementers, and stakeholders.

IV The new policy should incorporate priorities specific to geographic locations (like Terai, Hill, Mountain, Valley and Siwalik/Inner Terai) and take into account the differing density of livestock to result in regional balance within Nepal.

$\mathrm{V}$ There should be appropriate legislative backing to the national livestock policy to support and ensure its effective implementation and adjudication. Also in other countries where mixed crop-livestock production systems exist, policies have not successfully accommodated realities of a mountain environment where livestock are key to smallholder livelihood [30] .

VI An integrated approach to research and development (R\&D) should be developed for fostering new technologies and policies

VII A comprehensive and forward-looking policy environment should provide for policies to be updated and improved regularly [31].

VIII Livestock policy studies should be extended to accommodate the emerging concerns of socio-economic and national resources management and climate change mitigation and adaptation.

IX Political parties and mass organizations should be involved in livestock development programs.

$\mathrm{X}$ Participation of villagers, local government bodies (VDCs and DDCs), and NGOs as collaborators in livestock development activities must be encouraged.

XI The central government should bear the costs of developing livestock technologies that are in the national interest.

XII Each state (or province) in the new federal structure should identify livestock growth-axes and growth-centers for promoting commercial production.

XIII Public private partnerships (PPP) along with the appropriate involvement of cooperatives should be promoted in livestock development activities. As suggestions on policy content and planning:

I There should be adequate and well-placed investments in the livestock subsector from both public and private sectors to allow policy implementation. Nepal's government budget allocation for the entire agriculture sector has been meager and dwindling; in FY 2009/10, it figured only 2.75 percent of the total national outlay against 6.2 and 6 percent in Bangladesh and India respectively, and more than 4 percent even in conflict-hit African nations [32].

II The new policy should identify livestock projects that can be developed as strategic business units (SBUs), particularly for foreign-assisted projects. To identify such projects, past success stories and experiences in the livestock business can be used as benchmarks. There should be institutional arrangements and mechanisms for developing human resources required for farmer education, business development, and effective policy implementation.

(a) The newly established Agriculture and Forestry University (AFU) should be strengthened with a focus on developing human resources for livestock-promotion. There should also be 
roles for other existing universities, including Nepal's pioneer Tribhuvan University, and for private sector institutes working in the area.

(b) Organizational resources at the Centre for Technical Education and Vocational Training (CTEVT) should be effectively managed and mobilized to develop low-level extension workers and technicians for livestock activities.

III Commercialization and diversification need to be addressed in a broader context that incorporates the emerging challenges and opportunities offered by regional trade agreements like South Asian Free Trade Area (SAFTA) and Bay of Bengal Initiative for Multi-sectoral Technical and Economic Cooperation (BIMSTEC).

IV There should be policy thrusts and programs for promoting livestock marketing activities to establish stronger forward-linkages that provide farmers better access to market, so that livestock farmers can gain adequate returns from their outputs. Promote a marketing network, including livestock wholesale markets and haat bazaars (open-air retail markets), and centers for livestock information at central, provincial and local levels.

$\mathrm{V}$ In the new policy, there should be a well-functioning mechanism to channelize the livestock-related benefits envisaged directly to marginalized, disadvantaged communities

VI Socioeconomic issues related to gender, child-labor, markets, community and farmers groups all have direct implications on livestock activities and should be considered in developing the national livestock policy. There is a need to ensure women farmers' participation at all stages of livestock development planning. Women's role should not only be limited to livestock rearing and care, but extended to include marketing and finance. Policy on women's empowerment and participation should comply with Nepal's commitment to the Beyond Beijing Conference and other international conventions including the UN Declaration against Discrimination of Women and Men and Elimination of All Forms of Discrimination against Women. Livestock policy should address the problems arising from use of children in livestock farming.

VIII The new policy should promote projects to set up rainwater harvesting facilities that increase water and fodder for livestock.

IX The livestock policy should be developed and reviewed from the perspectives of (a) Improved cattle breeds; (b) Improved forage crops and modern varieties; and (c) animal health, including shelter from extreme weather and control of pathogens.

$\mathrm{X}$ It is important to make provisions to delegate responsibilities to local and community levels in appropriate areas:

(a) At the community levels, policies should make adequate provisions for backward linkages to promote livestock activities; they include, if are not limited to, pasture land management, animal health services, scientific breeding, and feed and forage management.

(b) Poor data in the LSS, especially in the areas of productivity, inputs, trade, improved breeds and agri-business, has been a hurdle in livestock development at the local and community level. A new livestock policy should establish an improved database and provide for constant updating and upgrading.

(c) A comprehensive strategy that coordinates various stakeholders in livestock development should be developed. Promotion of the free-market mechanism in the dairy business is 
deemed necessary and therefore the DDCN's current role as the price setter and controller need to be revisited and redefined. A market mechanism should ensure that dairy prices reflect geographic location differences, cross-border prices, general business cycles and the impact of rising costs, wages, utilities, and taxes.

(d) There can be provisions for subsidizing livestock-related technologies and also for exempting livestock products of small-holder farmers from central and state government taxes as well as local taxes. Nepalese who have returned from foreign employment should be encouraged to take up livestock raising, processing and marketing by providing entrepreneurial support and micro-credit facilities to promote local ecomomy.

The new policy should provide for proper institutional arrangements to perform regular evaluations and controlling functions, and obligate the line agencies and stakeholders to comply and correct the lapses or gaps discovered.

(a) A monitoring and evaluation system should be established and include the impact of livestock programs on national priorities like poverty alleviation and climate change monitoring.

(b) There is a need to review and strengthen the organizational framework and increase the capability of human resources for implementing policies.

(c) Technical and logistical assistance is needed to grassroots and village organizations for implementing resilience-building measures that promote long-term livestock development at specific locations.

\section{Conclusions}

There is an urgent need for formulating a separate, integrated national livestock policy and for implementing it with adequate institutional support and resources so that Nepal can sustainably increase livestock production and productivity and achieve diversification, commercialization and competitiveness of the livestock subsector to match the changing national and international contexts. The new policy needs to be pro-poor and inclusive to properly address the urgent national agendas of gender mainstreaming, livelihood vulnerability management, climate-change vulnerability management, and the protection and promotion of interests of underprivileged and indigenous communities and of economically underprivileged areas.

\section{Acknowledgements}

This work is part of the project "Adaptation for climate change by livestock smallholders in Gandaki river basin", supported by the USAID Feed the Future Innovation Lab for Collaborative Research for Adapting Livestock Systems to Climate Change at Colorado State University under subaward 9650-32. The authors are also thankful to The Small Earth Nepal. All statements made are the views of the authors and not the opinions of the granting agencies or the U.S. government.

\section{Author Contributions}

Upendra Pradhanang and Soni M. Pradhanang reviewed, analyzed and conducted SWOT analysis of the National Livestock Policies at various levels. Arhan Sthapit, Nir Krakauer, Ajay Jha, and 
Tarendra Lakhankar are involved in providing guidance and evaluating appropriateness of SWOT analysis presented in this paper.

\section{Conflicts of Interest}

The authors declare no conflict of interest.

\section{References}

1. NSCoA. National Sample Census of Agriculture-2011/12; Central Bureau of Statistics, National Planning Commission Secretariat, Government of Nepal: Kathmandu, Nepal, 2013.

2. Department of Agriculture, Ministry of Agricultural Development, Government of Nepal. Available online: http://www.doanepal.gov.np/ (accessed on 20 June 2014).

3. ADS. Ads Assessment Report, Agricultural Development Strategy Assessment; Government of Nepal, ADB, IFAD, EU, FAO, SDC, JICA, WFP, USAID, DANIDA, DfID and World Bank: Kathmandu, Nepal, 2012.

4. ILO. A Fair Globalization: Creating Opportunities for All; Report of the World Commission on the Social Dimension of Globalization: Geneva, Switzerland, 2004; p. 143.

5. MoAC. National Agriculture Policy; Ministry of Agriculture and Cooperatives, Government of Nepal: Kathmandu, Nepal, 2004.

6. NPC. Approach Paper to the Thirteenth Plan (Fiscal Year 2012/13-2015/16). National Planning Commission, Government of Nepal: Singh Durbar, Kathmandu, Nepal, 2012.

7. Shrestha, S. Contraction in Key Sector Hurt Growth Rate. The Himalayan Times, 8 April 2013.

8. Pearce, J.A., II; Robinson, R.B.; Mital, A. Strategic Management: Formulation, Implementation and Control, 12 ed. McGraw Hill: New Delhi, India, 2012.

9. NLC-Nepal. Interim Constitution of Nepal Nepal Law Commission, Kathmandu, Nepal, 2007.

10. MoAC. Agriculture Perspective Plan (App), 1995-2015; Government of Nepal: Kathmandu, Nepal, 1995.

11. MoF. Budget Speech of 2014/015; Ministry of Finance, Government of Nepal: Kathmandu, Nepal, 2013.

12. Sthapit, A. Boost Investment in Agriculture. The Rising Nepal, 10 November 2010.

13. Sthapit, A. Essentials of International Business \& Environment (with Case Studies), 2nd ed.; Asmita Books Publishers: Kathmandu, Nepal, 2013.

14. WIPO. International Classification of Goods and Services for the Purposes of the Registration of Marks; World Intellectual Property Organization: CH-1211 Geneva 20, Switzerland, 2014.

15. WTO. Standards and Trade Development Facility, STDF Newsletter; World Trade Organization, Official Website. Available Online: Http://Www.Wto.Org (accessed on 20 March 2014).

16. UNFCCC. United Nations Framework Convention on Climate Change; UNFCCC Secretariat: Bonn, Germany, 1992.

17. NAPA. National Adaptation Program of Action; Government of Nepal: Kathmandu, Nepal, 2010.

18. LAPA. Local Adaptation Program of Action; Government of Nepal: Kathmandu, Nepal, 2011.

19. Singh, T.M.; Sthapit, A. Human Resource Management: Text and Cases; Taleju Prakashan: Kathmandu, Nepal, 2008. 
20. ADB. Overview of Gender Equality and Social Inclusion in Nepal; Asian Development Bank: Kathmandu, Nepal, 2010.

21. UN-Women. Review of the Implementation of the Beijing Platform for Action (the Outcome Document of the Twenty-Third Special Session of the General Assembly); United Nations Women E/CN.6/2005/2; UN-Women: New York, NY, USA, 2004.

22. Maltsoglou, I.; Taniguchi, K. Poverty, Livestock and Household Typologies in Nepal; ESA Working Paper No. 04-15; Food and Agriculture Organization (FAO): Rome, Italy, 2004; pp. $1-48$.

23. Bom, P. Federal Governance Structure for Nepal. In Federal Structure Is Mandatory for Proportional Electoral System. Government of Nepal: Kathmandu, Nepal, 2007.

24. Piya, L.; Maharjan, K.L.; Joshi, N.P. Vulnerability of Rural Households to Climate Change and Extremes: Analysis of Chepang Households in the Mid-Hills of Nepal. In 28th International Conference of Agricultural Economists: The Global Bioeconomy; International Association of Agricultural Economists: Foz Do Iguacu, Brazil, 2012; No. 126191.

25. Pettengell, C. Climate Change Adaptation: Enabling People Living in Poverty to Adapt. OXFAM: Carlisle, UK, 2010.

26. Cameron, J. The Agricultural Perspective Plan: The Need for Debate. Himalaya. J . Assoc. Nepal Himal. Stud. 1988, 18, 8.

27. Ospina, A.V.H.R. Linking ICTs and Climate Change Adaptation; University of Manchester: Manchester, UK, 2010.

28. Panthi, J.; Dahal, P.; Shrestha, M.L.; Aryal, S.; Krakauer, N.Y.; Pradhanang, S.M.; Lakhankar, T.; Jha, A.K.; Sharma, M.; Karki, R. Spatial and Temporal Variability of Rainfall in the Gandaki River Basin of Nepal Himalaya. Climate 2015, 3, 210-226.

29. Parikh, J. Gender and Climate Change Framework for Analysis, Policy \& Action; IRADe and UNDP India: New Delhi, India, 2007.

30. Tulachan, P.M.; Partap, T. Development Experiences of Livestock Production Systems in Hindu Kush Himalayan Region. In Proceedings of An IDRC-ILRI International Workshop held at ILRI, Addis Ababa, Ethiopia, 11-15 May 1998; pp. 149-163.

31. PPTA Consultants. Preparation of the Nepal Agricultural Development Strategy; ADB project 43447-022; PPTA Consultants: Kathmandu, Nepal, 2012.

32. Sthapit, A. International Business: Text and Cases, 1st ed.; Taleju Prakashan: Kathmandu, Nepal, 2005.

(C) 2015 by the authors; licensee MDPI, Basel, Switzerland. This article is an open access article distributed under the terms and conditions of the Creative Commons Attribution license (http://creativecommons.org/licenses/by/4.0/). 